\title{
The Cumacea community of the southeastern Brazilian Continental Shelf: structure and dynamics*
}

\author{
MARIA FERNANDA L. DOS SANTOS and ANA MARIA S. PIRES-VANIN ${ }^{1}$ \\ Instituto Oceanográfico da Universidade de São Paulo, C.P.66149-05315-970 \\ São Paulo, Brazil. 'E-mail: amspires@ usp.br
}

\begin{abstract}
SUMMARY: Specific composition, abundance, diversity and dynamics of the Cumacea community from the southeastern Brazilian continental shelf were studied. The area is characterized by the intrusion of a cold and highly saline water mass in summer, the South Atlantic Central Water (SACW), from the slope towards the coast, changing the hydrographic structure of the shelf and the species distribution. During the other seasons the inner shelf, area shallower than $50 \mathrm{~m}$, is filled with warm and low saline water, the Coastal Water (CW). The presence of the SACW seems to favor the abundance and diversity of Cumacea due to its higher primary production and stability. Three groups of species were related to the water masses. Depth and fine sand fraction were shown to be the main factors structuring the Cumacea community. The role of the $\mathrm{SACW}$ in maintaining the Cumacea populations in the area through the passive transport of pre-ovigerous and ovigerous females is discussed.
\end{abstract}

Key words: Cumacea, Crustacea, benthic community, continental shelf, Brazil.

\section{INTRODUCTION}

Earlier studies on macrobenthic organisms were aimed at understanding the trophic relationships between bottom fauna and demersal fishes of economic interest. More recently intensive efforts have been made to determine the factors responsible for the spatial and temporal patterns in species distribution (McBee and Brehm, 1982; Aschan, 1990; Morrisey et al. ,1992).

Changes in benthic communities have been frequently correlated with depth (Day et al., 1971), temperature (Persson, 1982), salinity (Jones et al., 1986) or substrate composition (Weston,1988). However, the marine environment comprises an integrated series of gradient, which

\footnotetext{
*Received May 15, 1997. Accepted August 3, 1998.
}

influence the distribution and abundance of the species and reflect the local environmental complexity. Since the species are affected by many factors simultaneously, multivariate analysis techniques have been employed successfully to determine the relative importance of these factors in structuring the communities. This approach was followed herein.

The present study deals with the spatial and temporal structure of the Cumacea community. It is part of a broad interdisciplinary research program directed at understanding the structure and function of the continental shelf ecosystem in the Ubatuba region, southeastern Brazil.

Cumacea are infaunal peracarid crustaceans distributed worldwide, occuring from intertidal zone to abyssal depths (Jones, 1969). They live in the sediment, burrowing and feeding on organic matter. Due 
to their close relationship with the substrate, cumacean species can reflect the changes in the bottom environment, and constitute an important link in the demersal trophic web, being a frequent food item for many fish species.

Knowledge about biology and ecology of coastal Brazilian Cumacea is lacking. To close, only taxonomic studies have been carried out, i.e., of Brum (1966, 1970 and 1971), Bãcescu \& Queiroz (1985), Roccatagliata (1985, 1986 and 1989), Roccatagliata \& Moreira (1987), Bãcescu and Petrescu (1988 and 1991), Petrescu and Bãcescu (1991).

The present study investigates the composition and distribution of the species of Cumacea, determines their abundance and diversity, and evaluates the effects of the seasonal oceanographic changes upon the communities.

\section{AREA OF STUDY}

The area of study is located over the continental shelf of Ubatuba, southeastern Brazilian Bight, between São Sebastião Island and Ubatumirim Bay $\left(23^{\circ} 25^{\prime}\right.$ to $24^{\circ} 22^{\prime} \mathrm{S}$ and $44^{\circ} 33^{\prime}$ to $45^{\circ} 16^{\prime} \mathrm{W}$ ) (Fig. 1).

The continental shelf of Ubatuba can be divided both oceanographically and biologically into inner shelf (from coastline to $50 \mathrm{~m}$ depth), and outer shelf (from $50 \mathrm{~m}$ to $100 \mathrm{~m}$ depth) (Castro-Filho, et.al. 1987; Pires, 1992; Pires-Vanin, 1993). It can be divided into north, northeast, south and southwest parts according to its environmental characteristics and to the cumacean species distribution. The sediments present a complex pattern of distribution showing a variety of types. In general the northern area presents sandy bottoms whereas the southern area is muddy.

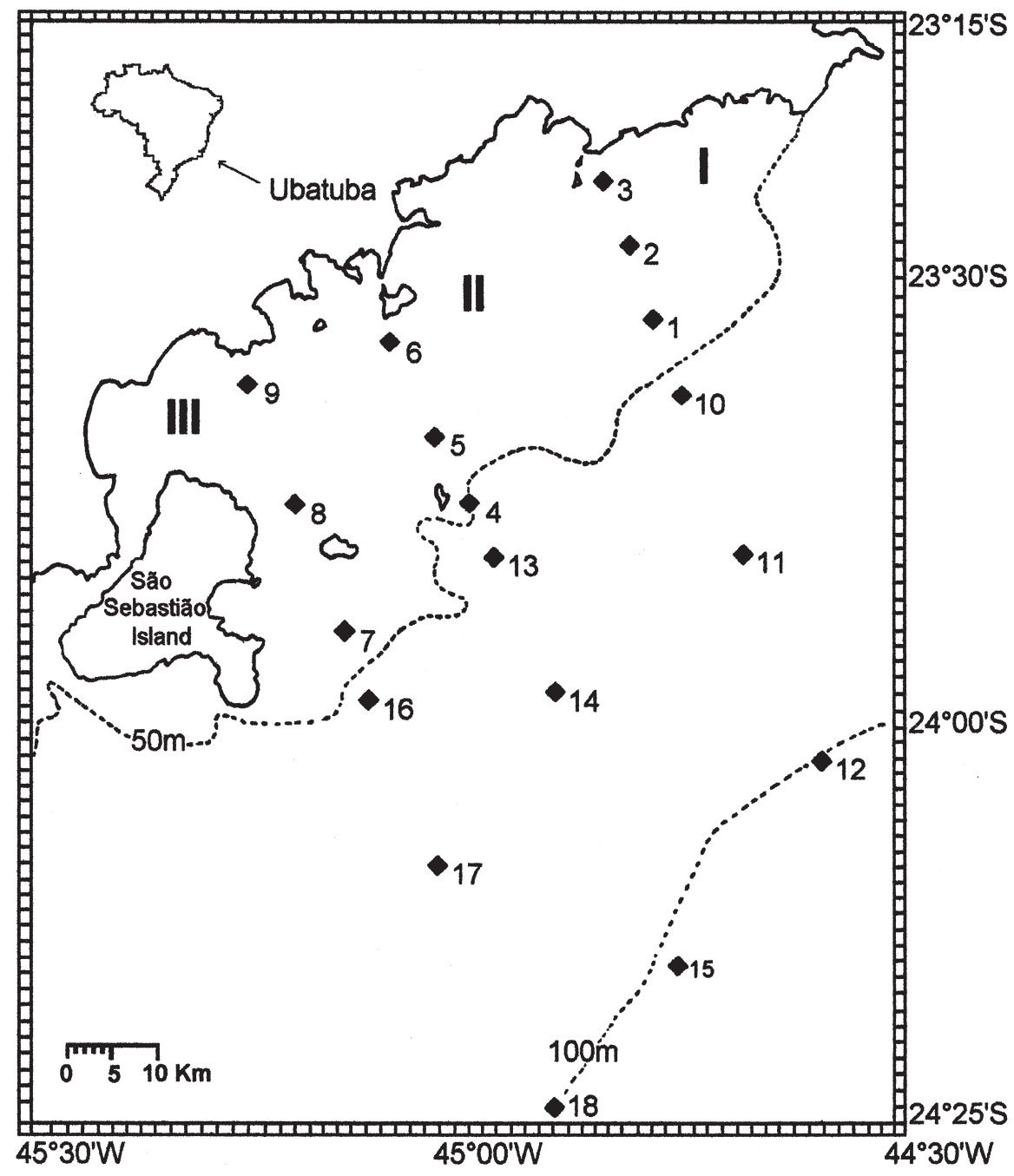

FIG. 1. - Area of study on the continental Brazilian shelf showing the sampling stations (1 to 18). 
Two water masses influence the sea bottom, and the oceanographic structure is opposite in summer and winter. During spring and summer, the South Atlantic Central Water (SACW) penetrates into the bottom layer of the coastal region and forms a strong thermocline in midwater. At the same time, Coastal Water (CW) is compressed along the coast, filling the superficial layer. By autumn and winter, the SACW retreats to the shelfbreak and is replaced by CW. More details about the oceanographic structure of Ubatuba region, can be found in Castro-Filho et al., 1987.

The SACW is rich in nutrients $(\mathrm{N}$ and $\mathrm{P})$ and when it reaches shallow areas $(<50 \mathrm{~m})$ in summer, promotes intense eutrophication, which increases the local primary production. Consequently, more food seems to be channeled to the benthos in summer, resulting in a seasonal variation of its biomass (Pires, 1992).

\section{MATERIAL AND METHODS}

Sampling was carried out at 18 sites located in three transects between 10 and $124 \mathrm{~m}$ depth, seasonally on the inner shelf ( 10 to $50 \mathrm{~m}$ depth, sites 1 to 9) and in summer and winter on the outer shelf (50 to $124 \mathrm{~m}$ depth, sites 10 to 18 ), from October 1985 to July 1987. A total of 108 samples were obtained (Fig. 1). Each sample was numbered according to its original site (1 to 18 ) plus a letter indicating the season of the year it was obtained ( $\mathrm{P}$ $=$ Spring, $\mathrm{S}=$ Summer, $\mathrm{A}=$ Autumn, $\mathrm{W}=$ Winter ).

Benthic macrofauna were collected with a 0.1 $\mathrm{m}_{\text {- van Veen }}$ grab, a rectangular dredge and a beamtrawl. Sediment samples were washed with water through sieves of 2.0, 1.0 and $0.5 \mathrm{~mm}$ mesh screen, and fixed in $70 \%$ alcohol. The sediment was sorted out and the organisms obtained were counted and identified to species level.

Depth, bottom water temperature, salinity and dissolved oxygen concentration were determined at each sampling site. Salinity was measured with an inductive salinometer according to the Pratical Salinity Unity, having no unity.

Sediment samples were collected for textural analysis. Grain size was determined by sieving and pipetting techniques (Suguio, 1973). Folk and Ward parameters (Folk and Ward, 1957) were obtained for granulometric classification. The quantity of total organic matter in the sediment was measured by oxidation with $\mathrm{H}_{2} \mathrm{O}_{2}$ (Gross, 1971).
Water mass temperature ranges were established as follows: $\mathrm{SACW}=13^{\circ} \mathrm{C} \leq \mathrm{T} \leq 17.9^{\circ} \mathrm{C}$; $\mathrm{SACW}$ $\mathrm{CW}=18^{\circ} \mathrm{C} \leq \mathrm{T} \leq 19.9^{\circ} \mathrm{C} ; \mathrm{CW}=\mathrm{T} \geq 20^{\circ} \mathrm{C}$.

Species abundance was expressed as number of individuals. Shannon's diversity index $(\mathrm{H})$ and evenness (J) were calculated with quantitative data from grab for summer and winter samples only, since outer shelf was sampled only at these seasons. The mean values obtained in each year of study were compared.

Pearson's correlation coefficient for diversity and physical parameters was calculated after data $\log$ transformation $[\mathrm{y}=\log (\mathrm{x}+1)]$.

Two binary matrices were produced with combined data obtained from the vanVeen grab, rectangular dredge and beam-trawl. Species present in two or less sampling sites were eliminated. The resulting matrices, 46 sites and 18 species and 42 sites and 16 species, were analyzed for the first and second year of study, respectively.

Cluster Analysis (Q-mode and R-mode), Multiple Discriminant Analysis, Principal Component Analysis (PCA) and Stepwise Multiple Linear Regression Analysis (SMLR) were employed to identify and interpret the spatial and temporal changes in Cumacea community. Cluster Q-mode grouped sites on the basis of similarity of faunal composition and R-mode considered the similarities between species according to their distributions. Clusters were calculated employing the Unweighted Pair-Group Method (UPGMA) and Jaccard's similarity coefficient. The code of the stations and species used in the multivariate analyses are in Table 3.

The physical data were standardized by reduction to values between 0 and 1 , before performing Multiple Discriminant Analysis. Site coordinates were considered as dependent variables and abiotic factors as independent variables in SMLR.

\section{RESULTS}

Nine physical parameters were analyzed for the area studied: depth, temperature, salinity, dissolved oxygen, organic matter, mean grain size, sand content, clay content and silt content.

During the first year of study mean bottom temperature was $18.4^{\circ} \mathrm{C}$ in spring, $16.9^{\circ} \mathrm{C}$ in summer, $22.4^{\circ} \mathrm{C}$ in autumn and $21.0^{\circ} \mathrm{C}$ in winter for inner shelf. In the second year values were $18.7^{\circ} \mathrm{C}$ in spring, $18.5^{\circ} \mathrm{C}$ in summer, $21.1^{\circ} \mathrm{C}$ in autumn and 

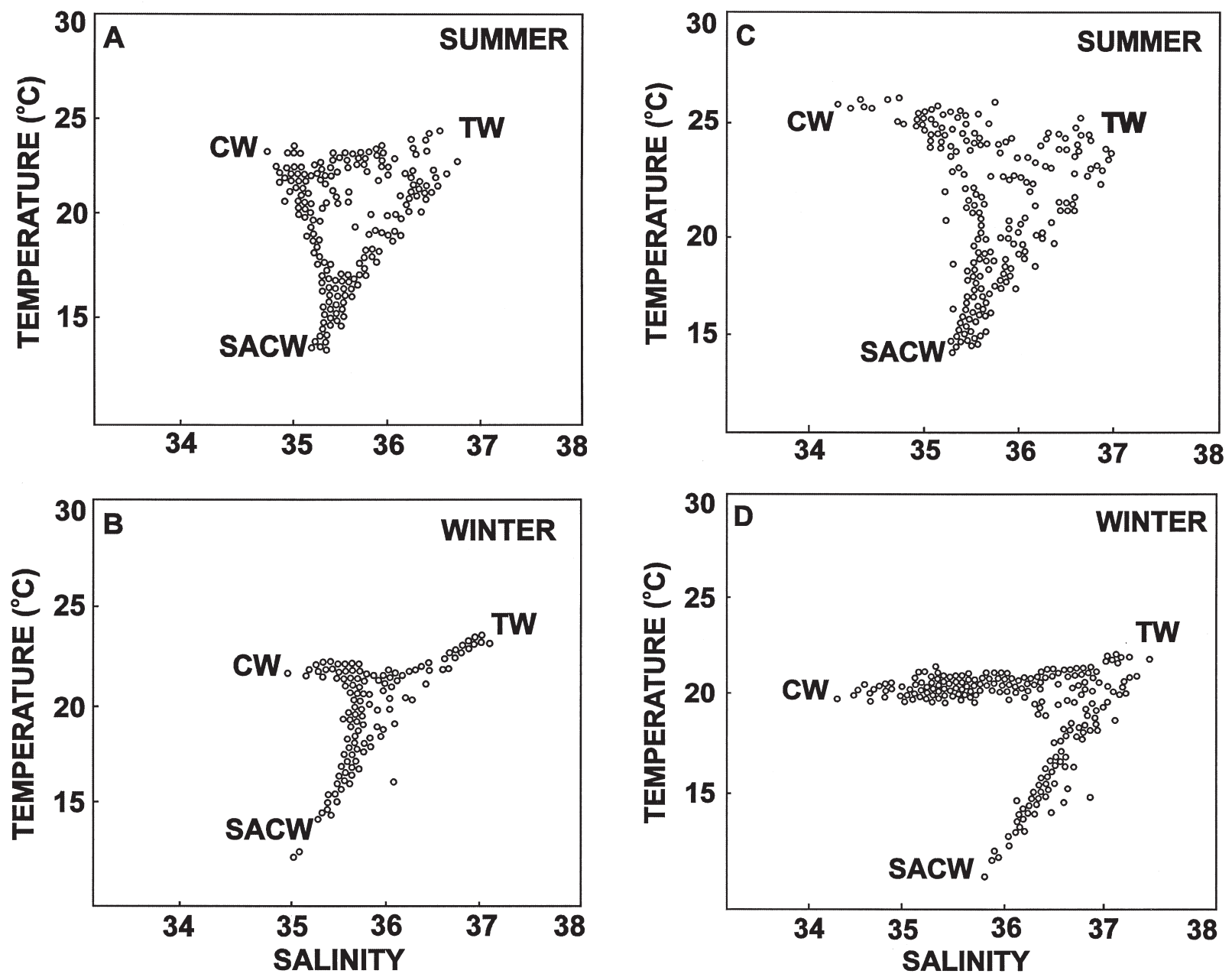

FIG. 2. - T-S diagram showing temperature and salinity pairs, sampled during Summer and Winter on inner and outer shelves for the first (A, B) and second (C, D) years of study. SACW: South Atlantic Central Water; CW: Coastal Water; TW: Tropical Water.

$20.8^{\circ} \mathrm{C}$ in winter. On the outer shelf mean temperature was $16.6^{\circ} \mathrm{C}$ in summer and $18.6^{\circ} \mathrm{C}$ in winter for the first year, and $15.2^{\circ} \mathrm{C}$ in summer and $17.0^{\circ} \mathrm{C}$ in winter for the second study period.

Differences in temperature between north and south parts from inner shelf were found chiefly in summer of the first year. The mean values were 17.7 ${ }^{\circ} \mathrm{C}$ (north) and $18.5^{\circ} \mathrm{C}$ (south) for the first year, and $19.4{ }^{\circ} \mathrm{C}$ (north) and $19.1{ }^{\circ} \mathrm{C}$ (south) for the second year.

The diagrams of temperature and salinity (T-S) for the water column and bottom layer showed the presence of three water masses: Coastal Water - CW $\left(\mathrm{T}>20^{\circ} \mathrm{C}, \mathrm{S}<36.0\right)$; South Atlantic Central Water SACW $\left(\mathrm{T}<17^{\circ} \mathrm{C}, \mathrm{S}<36.0\right)$; Tropical Water - TW ( $>20^{\circ} \mathrm{C}, \mathrm{S}>36.0$ ) (Fig. 2).

In the first year the SACW intruded on inner shelf to $15 \mathrm{~m}$ depth during summer, whereas it retreated to around $60 \mathrm{~m}$ depth in autumn and win- ter months. In the second year of study, the SACW penetration was less pronounced, reaching depths of $45 \mathrm{~m}$, and in winter it stayed as deep as $60 \mathrm{~m}$.

Salinity presented small spatial and temporal variation (34.4 to 36.1), in both years. The lower values were found near the coast, where Coastal Water predominated.

A bigger range of variability was found for the oxygen values at inner shelf. They varied from 2.35 to $5.77 \mathrm{ml} / 1$ and from 2.58 to $4.58 \mathrm{ml} / 1$ for the first and second year, respectively.

Organic matter presented higher values in the southwest part of the shelf, near to São Sebastião Island $(3.5 \%-3.8 \%)$, decreasing in the north and northeast areas. Smallest values $(0.1 \%-0.2 \%)$ were found between the 50 and $70 \mathrm{~m}$ isobaths for both years.

The sediment showed a heterogeneous distribution. The finer grain fraction (silt) was deposited in 
TABLE 1. - Average abundance $\left(\mathrm{n}^{\mathrm{o}}\right.$ ind. $\left./ 0.1 \mathrm{~m}^{2}\right)$ on the transects and during the seasons for the first and second yewars of the study

\begin{tabular}{|c|c|c|c|c|c|c|c|c|}
\hline \multirow[b]{2}{*}{ Year } & \multirow[b]{2}{*}{ Shelf } & \multicolumn{3}{|c|}{ Transects } & \multirow[b]{2}{*}{ Spring } & \multirow[b]{2}{*}{ Summer } & \multirow[b]{2}{*}{ Autumn } & \multirow[b]{2}{*}{ Winter } \\
\hline & & I & II & III & & & & \\
\hline First & $\begin{array}{l}\text { Inner } \\
\text { Outer }\end{array}$ & $\begin{array}{c}809 \\
32\end{array}$ & $\begin{array}{c}119 \\
91\end{array}$ & $\begin{array}{l}45 \\
38\end{array}$ & $\begin{array}{c}111 \\
-\end{array}$ & $\begin{array}{c}832 \\
91\end{array}$ & $\begin{array}{l}8 \\
-\end{array}$ & $\begin{array}{l}22 \\
70\end{array}$ \\
\hline Second & $\begin{array}{l}\text { Inner } \\
\text { Outer }\end{array}$ & $\begin{array}{c}314 \\
13\end{array}$ & $\begin{array}{l}40 \\
58\end{array}$ & $\begin{array}{l}10 \\
18\end{array}$ & $\begin{array}{l}6 \\
-\end{array}$ & $\begin{array}{c}334 \\
50\end{array}$ & $\begin{array}{l}2 \\
-\end{array}$ & $\begin{array}{l}23 \\
38\end{array}$ \\
\hline
\end{tabular}

the southern part of the area, from the coast to near $70 \mathrm{~m}$ depth and close to the $100 \mathrm{~m}$ isobath. Very fine sand tended to occupy most of the remaining sites, increasing with depth in the northeast part of the shelf. On the other hand, sand is deposited near the shelfbreak (fine sand) and northward (medium sand).

\section{Abundance}

During the period of study a total of 1587 individuals were obtained. The inner shelf contained more than $80 \%$ of all the specimens found. Seasonal variation in abundance was noticed for inner and outer shelves.

In the first year, higher abundance was observed in summer, with 832 individuals at inner shelf and 91 individuals on the outer shelf. Lower values were found on the inner shelf in autumn and winter. In the second year, higher values occurred during summer on the whole shelf. Considering inner shelf, abundance tended to be reduced towards the north in both years, while on the outer shelf higher values were obtained in transect II (Table 1).

\section{Diversity}

During the first year of the study the diversity values were correlated positively with depth $(0.38)$ and negatively with silt $(-0.41)$ and temperature ($0.36)$. In the second year they presented negative correlation with clay $(-0.49)$, silt $(-0.49)$ and mean grain size $(-0.37)$.

In the first year, higher values of diversity occurred during the summer on the whole shelf. The mean values of evenness increased from coast to outer shelf in summer while in winter they were similar. In general, higher values of diversity were observed in transects I and II, during the first year, with a tendency to be reduced in the southern part of the shelf. On the other hand, the evenness indices were high and almost similar in all transects tending to increase towards the outer shelf. The lowest value was found in transect I at inner shelf and the highest value also in transect I but on the outer shelf. Slightly higher indices were noticed in wintertime for the whole shelf.

In the second year the same tendencies for diversity were observed but the mean values of evenness were higher. The highest evenness occurred on the outer shelf in transect I, due to the high number of species with few individuals (Table 2).

\section{Faunal dynamics}

For the first year of study, the dendrogram among sites showed two distinct groups in the first branch, both related with the presence of water masses and depth (Groups A and B) (Fig. 3). Group A consists of shallow sites ( $<20 \mathrm{~m}$ depth) under CW dominance and composed of Diastylopsis sp1. Group B comprises sites deeper than $20 \mathrm{~m}$, where SACW and SACW-CW are present.

Groups $\mathrm{C}$ and $\mathrm{D}$ are seen in the second branch. Group C includes sites between $20 \mathrm{~m}$ and $50 \mathrm{~m}$

TABLE 2. - Average species diversity (H') and evenness (J) on the transects and during the seasons for the first and second years of the study.

\begin{tabular}{|c|c|c|c|c|c|c|c|}
\hline \multirow{3}{*}{$\begin{array}{l}\text { Year } \\
\text { First }\end{array}$} & \multirow{3}{*}{$\begin{array}{l}\text { Shelf } \\
\text { Inner }\end{array}$} & \multirow{4}{*}{$\begin{array}{c}\text { Index } \\
\mathrm{H}^{\prime} \\
\mathrm{J}\end{array}$} & \multicolumn{3}{|c|}{ Transects } & \multirow{2}{*}{\multicolumn{2}{|c|}{ Summer Winter }} \\
\hline & & & \multirow{3}{*}{\begin{tabular}{c}
\multicolumn{1}{c}{ I } \\
1 \\
0.80
\end{tabular}} & \multirow{3}{*}{$\begin{array}{c}\text { II } \\
0.77 \\
0.90\end{array}$} & \multirow{2}{*}{$\begin{array}{c}\text { III } \\
0.78 \\
0.83\end{array}$} & & \\
\hline & & & & & & 1.06 & 0.94 \\
\hline & & & & & & & \\
\hline & Outer & $\mathrm{H}^{\prime}$ & 1.49 & 1.98 & 1.21 & 1.77 & 1.40 \\
\hline & & $\mathrm{J}$ & 0.95 & 0.91 & 0.90 & 0.89 & 0.94 \\
\hline Second & Inner & $\mathrm{H}^{\prime}$ & 1.12 & 1.47 & 0.32 & 1.16 & 1.05 \\
\hline & & J & 0.95 & 0.91 & 0.90 & 0.91 & 0.99 \\
\hline & Outer & $\mathrm{H}^{\prime}$ & 0.86 & 0.74 & 2.71 & 1.18 & 1.35 \\
\hline & & $\mathrm{J}$ & 1.00 & 0.92 & 0.96 & 0.99 & 0.91 \\
\hline
\end{tabular}



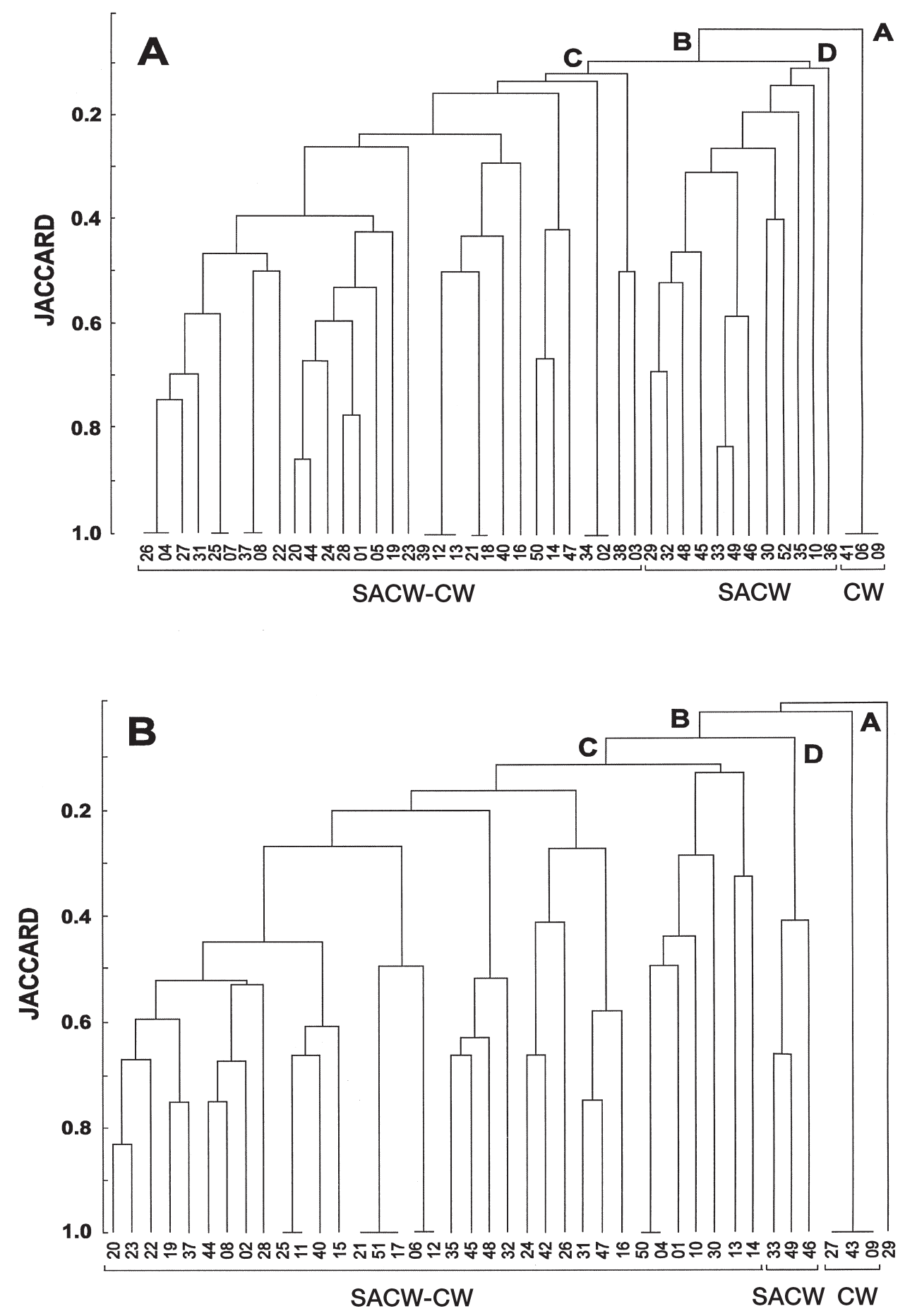

FIG. 3. - Dendrograms showing groups of stations formed by Cluster Analysis (Q-mode) for the first (A) and second (B) years of study. SACW: South Atlantic Central Water; CW: Coastal Water. Stations code numbers are shown in Table 31.

depth under influence of the two water masses, SACW and SACW-CW. Diastylis planifrons, Diastylis sp1, Anchistylis sp1, Cyclaspis variabilis, and Leptocuma kinbergii form it. Group D englobes sites deeper than $70 \mathrm{~m}$, always in the SACW domain, and contains Diastylis planifrons and Diastylis sp1.
The R-mode dendrogram shows in the first branch, Diastylopsis sp1 clearly separated from the other species (Group A) (Fig. 4). Diastylopsis sp1 was found only in the shallow sites $(<20 \mathrm{~m}$ depth) under $\mathrm{CW}$ influence. The second branch encompasses groups C and D. Group C contains Diastylis sp1, Diastylis planifrons and Anchistylis sp1, species that 

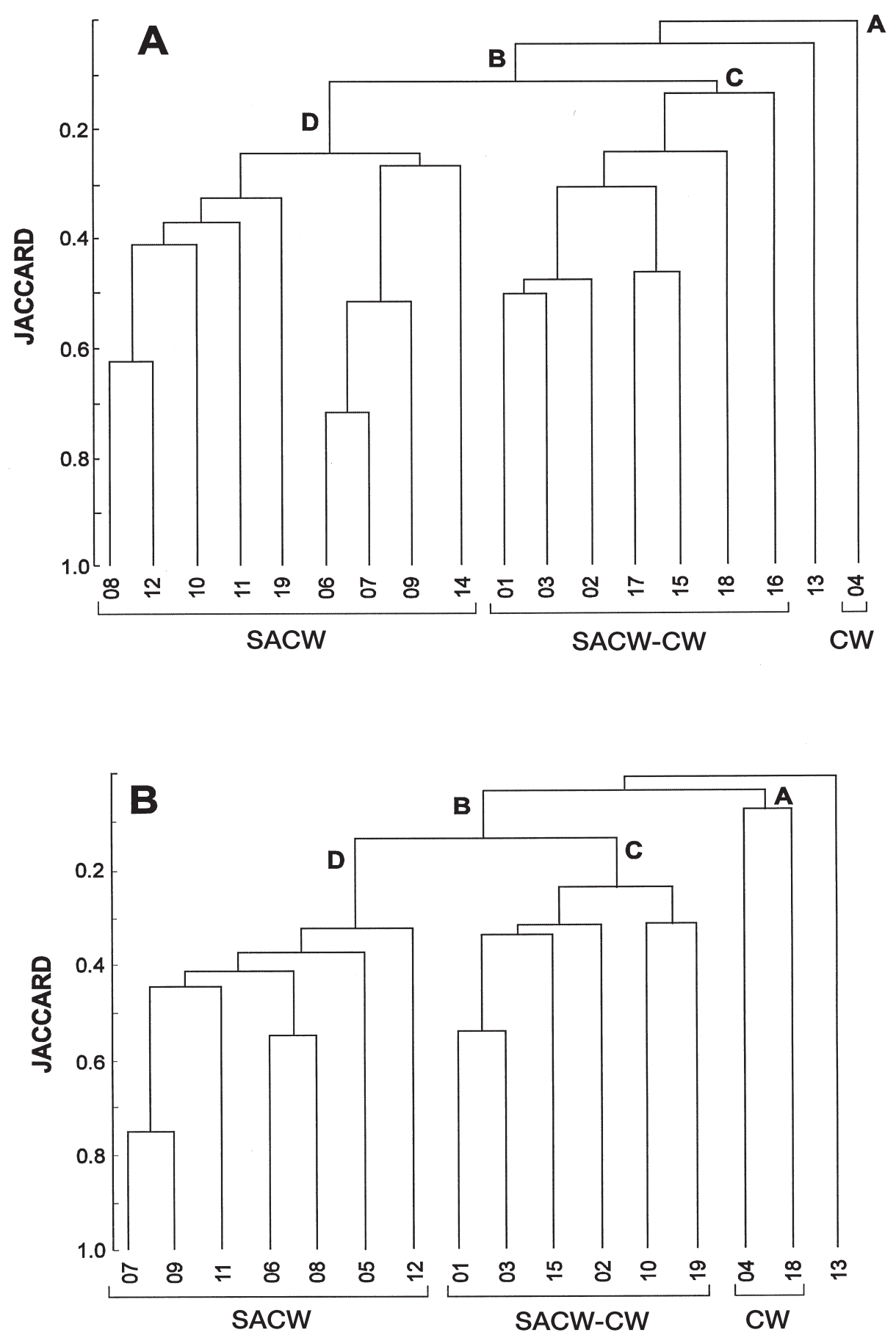

FIG. 4. - Dendrograms showing groups of species formed by Cluster Analysis (R-mode) for the first (A) and second (B) years of study. SACW: South Atlantic Central Water; CW: Coastal Water. Species code numbers are shown in Table 3.

occur between $20 \mathrm{~m}$ and $70 \mathrm{~m}$ depth, besides Cyclaspis sp2 and Cyclaspis variabilis, species from below 50 m. Group D comprises Campylaspis sp3, Apocuma brasiliense, Cumella argentinae, Campylaspis sp1, Campylaspis sp2 and Campylaspis sp4, species which live deeper than $70 \mathrm{~m}$, under the SACW dominance during all the year round.
Multiple Discriminant Analysis was performed considering the three main groups formed in the Qmode dendrogram. The discriminant function 1 accounts for $87.85 \%$ of total variance, having a large contribution of depth in positive correlation, and the mean grain size, silt and median sand in negative correlation. Function 1 separates group D in the pos- 
TABLE 3. - List of species and sampling stations with their respective code numbers included in Cluster Analysis. Stations 4W and $8 \mathrm{~W}$ excluded by Cumacea absence.

\begin{tabular}{|c|c|c|c|}
\hline \multirow{2}{*}{$\begin{array}{c}\text { Code of species } \\
\text { 1. Diastylis planifrons }\end{array}$} & \multicolumn{3}{|c|}{ Code of stations } \\
\hline & 1. $1 \mathrm{P}$ & 19. $1 \mathrm{~S}$ & $37.1 \mathrm{~W}$ \\
\hline 2. Diastylis sp. 1 & 2. $2 \mathrm{P}$ & $20.2 S$ & $38.2 \mathrm{~W}$ \\
\hline 3. Anchistylis sp. 1 & 3. $3 \mathrm{P}$ & $21.3 \mathrm{~S}$ & $39.3 \mathrm{~W}$ \\
\hline 4. Diastylopsis sp. 1 & 4. $4 \mathrm{P}$ & 22. $4 \mathrm{~S}$ & $40.5 \mathrm{~W}$ \\
\hline 5. Campylaspis brasiliana & 5. 5P & 23. $5 \mathrm{~S}$ & $41.6 \mathrm{~W}$ \\
\hline 6. Campylaspis sp. 1 & 6. $6 \mathrm{P}$ & 24. $6 \mathrm{~S}$ & $42.7 \mathrm{~W}$ \\
\hline 7. Campylaspis sp. 2 & 7. $7 \mathrm{P}$ & $25.7 \mathrm{~S}$ & 43. $9 \mathrm{~W}$ \\
\hline 8. Campylaspis sp. 3 & 8. $8 \mathrm{P}$ & 26. $8 \mathrm{~S}$ & 44. $10 \mathrm{~W}$ \\
\hline 9. Campylaspis sp. 4 & 9. $9 \mathrm{P}$ & 27. $9 \mathrm{~S}$ & $45.11 \mathrm{~W}$ \\
\hline 10. Cumella argentinae & 10. $1 \mathrm{~A}$ & 28. $10 \mathrm{~S}$ & 46. $12 \mathrm{~W}$ \\
\hline $\begin{array}{l}\text { 11. Cumella sp. } 1 \\
\text { 12. Apocuma brasiliense }\end{array}$ & $\begin{array}{l}\text { 11. } 2 \mathrm{~A} \\
\text { 12. } 3 \mathrm{~A}\end{array}$ & $\begin{array}{l}\text { 29. } 11 \mathrm{~S} \\
\text { 30. } 12 \mathrm{~S}\end{array}$ & $\begin{array}{l}47.13 \mathrm{~W} \\
48.14 \mathrm{~W}\end{array}$ \\
\hline 13. Leptocuma kinbergii & 13. $4 \mathrm{~A}$ & $31.13 \mathrm{~S}$ & 49. $15 \mathrm{~W}$ \\
\hline 14. Cyclaspis dentifrons & 14. $5 \mathrm{~A}$ & 32. $14 \mathrm{~S}$ & $50.16 \mathrm{~W}$ \\
\hline 15. Cyclaspis variabilis & 15. $6 \mathrm{~A}$ & 33. $15 \mathrm{~S}$ & $51.17 \mathrm{~W}$ \\
\hline 16. Cyclaspis sp.1 & 16. $7 \mathrm{~A}$ & 34. $16 \mathrm{~S}$ & $52.18 \mathrm{~W}$ \\
\hline 17. Cyclaspis sp. 2 & 17. $8 \mathrm{~A}$ & $35.17 \mathrm{~S}$ & \\
\hline 18. Eudorella sp.1 & 18. $9 \mathrm{~A}$ & 36. $18 \mathrm{~S}$ & \\
\hline 19. Leucon sp.1 & & & \\
\hline
\end{tabular}

itive side of the axis from groups $\mathrm{A}$ and $\mathrm{C}$ in the negative side. The discriminant function 2 corresponds to $12.15 \%$ of total variance and the variables, which contribute to axis formation, are dissolved oxygen and organic matter in positive correlation, and coarse sand, fine sand, clay, temperature and salinity in negative correlation. Function 2 separates group $\mathrm{A}$ in the positive side from group $\mathrm{C}$ in the negative side of the axis (Table 4).

Principal Component Analysis (Fig. 5), indicated the first four factors as responsible for $55.7 \%$ of the total explained variance, and axis I and II together corresponded to $42.1 \%$. The other factors contributed to $9.7 \%$ (factor III) and $7.9 \%$ (factor IV) of the variance.

According to the Stepwise Multiple Linear Regression, the first axis was correlated to five variables. Depth showed the highest positive correlation with axis I followed by coarse sand. Temperature, silt and mean grain size were negatively correlated.

TABLE 4. - Relative percentage of the discriminant function 1 and 2 and the correlation coeficients of environmental parameters for the first and second year of study. The data correlation were standartized.

\begin{tabular}{|c|c|c|c|c|c|c|c|c|c|c|c|c|c|}
\hline \multirow[b]{2}{*}{ Year } & \multirow[b]{2}{*}{$\begin{array}{l}\text { Discriminant } \\
\text { Function }\end{array}$} & \multirow[b]{2}{*}{$\begin{array}{l}\text { Relative } \\
\text { Percentage }\end{array}$} & \multicolumn{9}{|c|}{ Parameters } & \multirow[b]{2}{*}{ Silt } & \multirow[b]{2}{*}{$\begin{array}{r}\text { Mean grain } \\
\text { size }\end{array}$} \\
\hline & & & Depth & Temperature & Salinity & $\begin{array}{c}\text { Oxigen } \\
\text { dissolved }\end{array}$ & $\begin{array}{l}\text { Organic } \\
\text { matter }\end{array}$ & $\begin{array}{c}\text { Coarse } \\
\text { sand }\end{array}$ & $\begin{array}{l}\text { Median } \\
\text { sand }\end{array}$ & $\begin{array}{l}\text { Fine } \\
\text { sand }\end{array}$ & Clay & & \\
\hline \multirow[t]{2}{*}{ First } & 1 & 87.85 & 0.92 & 0.14 & -0.07 & 0.18 & -0.007 & -0.88 & -0.73 & -0.92 & 0.37 & -0.41 & -0.84 \\
\hline & 2 & 12.15 & -0.08 & -0.66 & -0.34 & 0.73 & 0.53 & -2.90 & -0.67 & -2.65 & -1.00 & -0.27 & -0.30 \\
\hline \multirow[t]{2}{*}{ Second } & 1 & 80.50 & 1.12 & -0.24 & -0.57 & 0.31 & 0.38 & -3.22 & 1.04 & -4.92 & -1.60 & -3.91 & 2.32 \\
\hline & 2 & 19.50 & -0.35 & -0.38 & -0.43 & 0.53 & -0.28 & -4.54 & -1.35 & -8.32 & -2.89 & -4.96 & 2.14 \\
\hline
\end{tabular}

TABle 5. - The fitted Model, Pearson's correlation $\left(\mathrm{r}^{2}\right)$ and parameters contribution to variabilities in axes I and II (\%) of the PCA.

\begin{tabular}{|c|c|c|c|c|c|c|c|c|c|c|c|}
\hline \multirow[b]{2}{*}{ Year } & \multirow[b]{2}{*}{ Axis } & \multirow[b]{2}{*}{ Model } & \multirow[b]{2}{*}{ Index } & \multicolumn{8}{|c|}{ Parameters } \\
\hline & & & & Depth & Temperature & $\begin{array}{l}\text { Oxygen } \\
\text { dissolved }\end{array}$ & $\begin{array}{c}\text { Coarse } \\
\text { sand }\end{array}$ & Fine sand & Silt & Clay & $\begin{array}{l}\text { Mean grain } \\
\text { size }\end{array}$ \\
\hline \multirow{4}{*}{ First } & & & $r^{2}$ & 0.67 & -0.48 & 0.06 & 0.31 & 0.04 & -0.40 & 0.10 & -0.30 \\
\hline & I & $60.6 \%$ & $\%$ & 45.3 & 0.2 & 2.6 & 1.5 & 0.1 & 4.7 & - & - \\
\hline & & & $r^{2}$ & -0.17 & -0.19 & -0.18 & -0.18 & 0.40 & -0.32 & -0.18 & -0.06 \\
\hline & II & $37.2 \%$ & $\%$ & 3.8 & 4.3 & 1 & 3.8 & 15.9 & 0.40 & 0.60 & - \\
\hline \multirow{4}{*}{ Second } & & & $r^{2}$ & 0.48 & -0.41 & 0.17 & 0.14 & 0.24 & -0.40 & -0.31 & -0.43 \\
\hline & I & $62.5 \%$ & $\%$ & 23.0 & 1.2 & 0.2 & 2.2 & 6.4 & 1.2 & 1.2 & 10.5 \\
\hline & & & $r^{2}$ & 0.26 & 0.02 & 0.31 & 0.19 & -0.31 & 0.22 & 0.12 & 0.06 \\
\hline & II & $53.0 \%$ & $\%$ & 4.5 & 3.0 & 14.0 & 0.7 & 9.7 & 3.8 & 1.4 & 8.7 \\
\hline
\end{tabular}

r critical: 0.291 (first year), 0.308 (second year) 

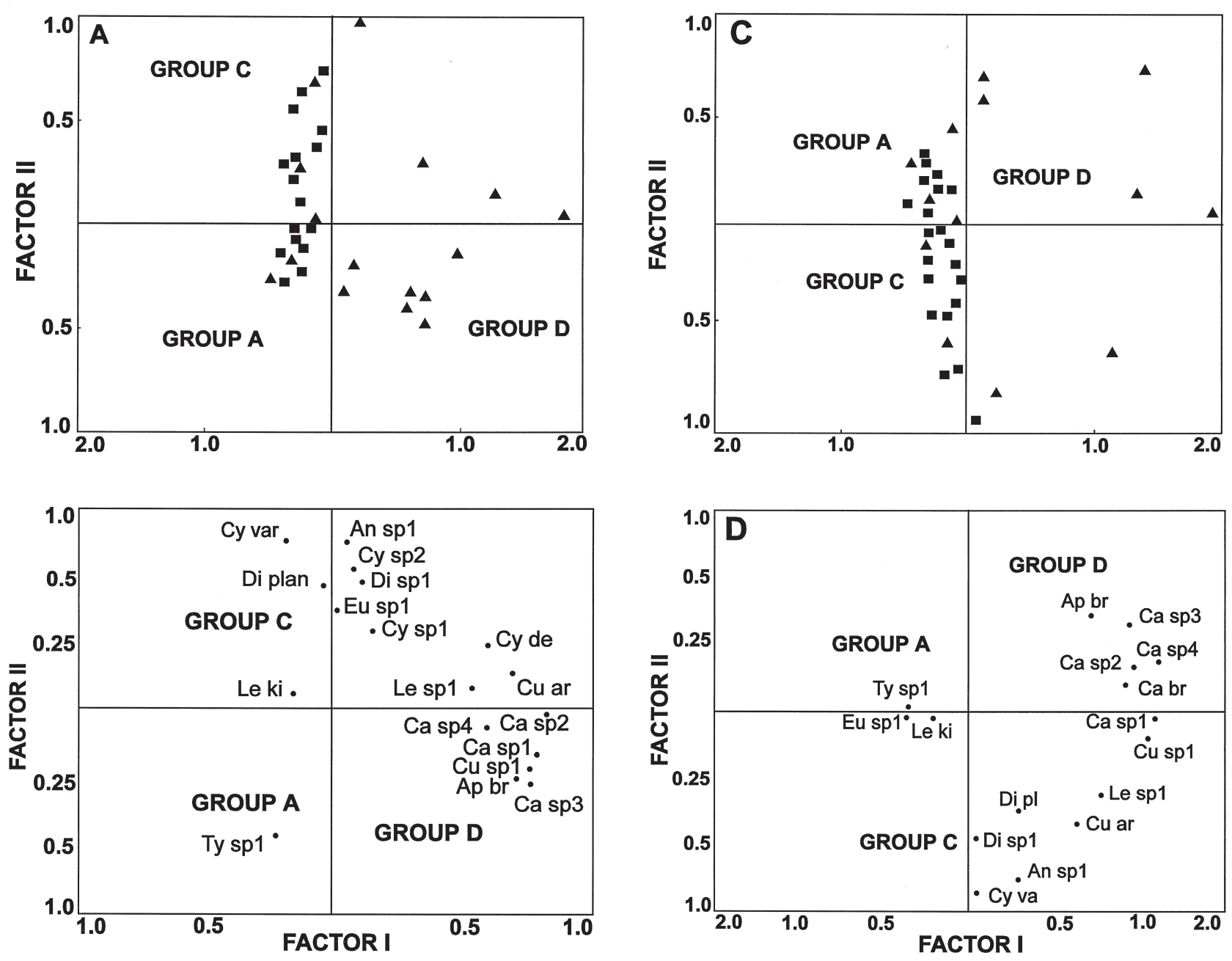

FIG. 5. - Principal Component Analysis of the first (A, B) and second (C, D) year of study. Distribution of species (B, D) and stations (A, C) are shown as a function of the first two axes. $\mathrm{s}=>50 \mathrm{~m} ; \mathrm{n}=<50 \mathrm{~m}$.

The fitted model explained $60.6 \%$ of the axis I variability. Among the parameters analyzed depth explained $45.3 \%$ of the variability in axis I. The second axis showed positive correlation with fine sand and negative with silt, and explained $37.2 \%$ of the total variance (Table 5).

Axis I separates sites deeper than $70 \mathrm{~m}$ depth, under SACW influence, and sediment mainly constituted by coarse sand (group D), from sites shallower than $50 \mathrm{~m}$ depth under SACW or SACW-CW dominance and sediment composed of fine particles. So this axis separates both species living exclusively on the inner shelf $(<50 \mathrm{~m})$ and species whose distribution extend to $70 \mathrm{~m}$ depth (Group A and Group C) from species occurring only on the outer shelf $(>70 \mathrm{~m}$ ) (Group D). Axis II separates sites where fine sand predominates (part of Groups C and D) from sites with high percentage of silt in the sedi- ment composition (Group A, part of Groups C and D ) (Fig. 5).

The same analyses were carried out with the second year data set. The results were similar to those of the first year, including the same species composition. Concerning Cluster Analysis and Principal Component Analysis, the groups obtained were also related to depth and water masses ( $\mathrm{SACW}$ and $\mathrm{CW}$ ), and depth and fine sand fraction explained axes I and II variability (Figs 3, 4, 5).

\section{DISCUSSION}

The striking fluctuations in species abundance at inner shelf can be explained by the hydrographic structure and, indirectly, by the differential quantities of food supply. 
During autumn and winter, the main source of organic matter to the benthic fauna originates from the nutrient remineralization process. However, in late spring and summer, SACW penetration eutrophicates inner shelf, increasing primary production and consequently the food supply to the bottom (Aidar et al., 1993; Pires-Vanin, 1993).

The presence of cold water and the availability of food, are probably the causes for the increase of species abundance on inner shelf in summer. During autumn and winter, as the SACW retreats, the water becomes warm, and stenothermic species disappear from the area decreasing the total abundance of the Cumacea. The inner shelf of Ubatuba region is characterized by a remarkable seasonal change in the hydrographic structure, and by the proximity of the coastline and the presence of many islands. The islands, mainly São Sebastião Island in the south, reduce the impact of waves from the open sea over the coast, and help to raise the quantities of suspended organic matter, silt and clay, increasing consequently the input of food to the benthos. On the other hand, the outer shelf is more stable regarding thermal variability and sediment composition. The thermal variations observed are directly related to the summer SACW penetration toward the shelf.

Temperature and food availability can influence crustacean reproduction also (Vernberg and Vernberg, 1983). As usually reproduction occurs in a narrow range of environmental conditions, the thermal seasonal changes observed on the coastal zone studied could influence the development of the Cumacea species, retarding their sexual maturity, modifying the reproductive periodicity and the number of eggs per brood, influencing thus the population abundance.

Besides temperature, alteration in substrate caused by biological disturbance, predation and sediment resuspension, is another important factor to be considered for explaining the reduction of the Cumacea abundance at inner shelf in autumn and winter. It is well known the role of grain size in determining the distribution of the Cumacea (Wieser, 1956). As it is straightly related to the feeding habit and to the respiratory mechanism of the species (Dixon, 1944), changes in sediment composition is fundamental for the species survival.

The observed tendency for the abundance reduction from north to south, can be probably linked to the high percentage of silt in the sediment. The Cumacea possess a filtering process in which fine particles of sediment can obstruct the respiratory apparatus and cause death of the species. This process is probably very important from the ecological point of view, since it determines the particle size that can effectively be filtered, acting as a limiting factor for species settlement.

The low values obtained for diversity on the inner shelf are due to a high dominance of some species of Cumacea, which probably indicates a certain environmental instability caused by the seasonal changes in hydrographic structure and the fluctuations of organic matter inputs from SACW and the continent.

The extent of the SACW penetration on the inner shelf varies from one year to another. The water entrance causes a thermal instability in that area during spring and summer, which has a direct influence on the species diversity observed. The positive correlation of diversity with depth, and negative correlation with silt, clay and mean grain size suggests an increase of diversity towards deeper zones, where environmental stability is higher. The presence of the SACW on the outer shelf favors the uniformity of the hydrographic structure, and also a constant supply of food of pelagic origin, contributing to a stability that is reflected in the high evenness values found, mainly in summer. The coarse particles deposited on the outer shelf also contribute to a structural complexity of the sediment, providing potential niche to many species and increasing diversity.

The most important factors responsible for the structure and maintenance of the Cumacea community were depth and fine sand fraction. Depth and the seasonality of the SACW penetration divided the continental shelf into two areas, inner and outer, both varying in the biotic and abiotic components and housing distinct groups of species, which were evidenced in Cluster and Principal Component Analyses. Several authors working in the Ubatuba shelf found also depth and water masses to be structuring factors for the benthic communities (Paiva, 1993; Pires, 1992; Sumida and Pires-Vanin, 1997).

The importance of the fine sand fraction for the Cumacea community is probably due to the high surface/volume ratio found in these particles and to the high food supply they contain. The deposit feeders show narrow sediment type and grain size request. Neither from too large nor from too small grains food can be extracted efficiently.

Besides changing the environmental conditions of the continental shelf, the SACW penetration also can be an effective mechanism for transporting the 
Cumacea species from deeper to shallower zones. This passive transport occurs through the moving water during the vertical migration of the species, and it can be a very important dispersal agent of preovigerous and ovigerous females favoring the colonization of new areas. So, many species living in deep zones would reach the inner shelf of Ubatuba in the SACW flow. This enhanced mobility would enlarge their area of distribution allowing the search of environments with new resources.

\section{ACKNOWLEDGEMENTS}

The authors wish to thank the "Comissão Interministerial para os Recursos do Mar" (CIRM), the "Consellho Nacional de Pesquisa e Tecnologia" (CNPq) for financial support, and the students and technicians from Benthic Ecology Laboratory, Oceanographic Institute of the University of São Paulo, for their help in sorting the samples. Thanks are also due to the reviewers Les Watling and D. Roccatagliata for comments on the manuscript.

\section{REFERENCES}

Aidar, E., S.A. Gaeta, S.M.F. Gianesella-Galvão, M.B.B. Kutner and C. Teixeira. - 1993. Ecossistema costeiro subtropical: nutrientes dissolvidos, fitoplâncton e clorofila-a e suas relações com as condições oceanográficas na região de Ubatuba, SP. Publção esp. Inst. oceanogr., 10: 9-43.

Aschan, M. - 1990. Changes in soft bottom macrofauna communities along environmental gradients. Ann. Zool. Fennici, 27: 329-336.

Bãcescu, M. and E.L. Queiroz. - 1985. The contribution of Cumacea in the feeding of the rajidae Sympterygia acuta and $S$. bonapartei from Rio Grande do Sul - RS - Brazil. Trav. Mus. Hist. nat. "Gr. Antipa”, 27: 7-18.

Bãcescu, M and I. Petrescu. - 1989. Contribution to the knowledge of the Campylaspis species (Crustacea, Cumacea) from the southern littoral waters of Brazil. Rev. Roum. Biol. - Biol. Anim., 34(2): 65-71.

Bãcescu, M and I. Petrescu. - 1991. New Cumacea (Crustacea, Peracarida) from the littoral waters of Brazil. Trav. Mus. Hist. nat. "Grigoire Antipa”, 31: 327-340.

Brum, I.N.S. - 1966. Oxyurostylis salinoi sp. n. do litoral brasileiro (Crustacea - Cumacea). Revta. bras. Biol., 26(1): 59-67.

Brum, I.N.S. - 1970. Ocorrência de Leptocuma kinbergii G.O. Sars (1873), no litoral brasileiro (Crustacea : Cumacea). Revta. bras. Biol., 30(1): 87-90.

Brum, I.N.S. - 1971. Nova espécie brasileira do gênero Makrokylindrus Stebbing, 1912. Bolm. Mus. Nac., 281: 1-7.

Castro-Filho, B.M. de, L.B. de Miranda and S.Y. Myao. - 1987. Condições hidrológicas na plataforma continental ao largo de Ubatuba: Variações sazonais e em média escala. Bolm. Inst. oceanogr., 35(2): 135-151.

Day, J.H., J.G. Field, and M.P. Montgomery. - 1971. The use of numerical methods to determine the distribution of the benthic fauna across the continental shelf of North Carolina. J. Anim. Ecol., 40: 93-125.
Dennell, R. - 1934. The feeding mechanism of the Cumacean Crustacean Diastylis bradyi. Trans. R. Soc. Edinb., 58(6): 125-142.

Dixon, A.Y, - 1944. Notes on certain aspects of the biology of Cumopsis goodsiri (Van Beneden) and some others cumaceans in relation to their environment. J. mar. biol. Ass. U.K. , 26: 61-71.

Folk, R.L and W.C. Ward. - 1957. Brazos River bar: a study of the significance of grain size parameters. J. Sedim. Petrology, 27: 3-26.

Gross, M.E. - 1971. Carbon determination. In: R.E. Carvier (ed), Producers in Sedimentary Petrology, pp. 573 -.596. Wiley Interscience, New York.

Jones. N.S. - 1969. The systematics and distribution of Cumacea from depths exceedings 200 meters. Galathea Rep. 10: 99-180.

Jones, A.R., C.S. Watson-Russel and A. Murray. - 1986. Spatial patterns in the macrobenthic communities of the Hawkesbriry estuary, New South Wales. Aust. J. mar. Freshwat. Res., 37: 521-543.

McBee, J.T. and W.T. Brehm. - 1982. Spatial and temporal patterns in the macrobenthos of St. Louis bay, Mississipi. Gulf Res. Dep., 7(2): 115-124.

Morrisey, D.J. , A.J. Underwood, L. Howitt and J.S. Stark. - 1992. Temporal variation in soft sediment benthos. J. Exp. Mar. Biol. Ecol., 164(2): 233-245.

Legendre, L. and P. Legendre. - 1983. Numerical Ecology. Developments in Environment Modelling, 3. Elsevier Scientific Publishing Company.

Paiva, P.C. - 1990. Padrões de distribuíção e estrutura trófica dos anelídeos poliquetas da plataforma continental do Litoral Norte do Estado de São Paulo. Dissertação de mestrado. Universidade de São Paulo.

Persson, L.E. - 1982. Macrozoobenthic associations of Hano Bight , Southern Baltic. Sarsia, 74(2): 137-144.

Petrescu, I. and M. Bãcescu. - 1991. A new contribution to the knowledge of the cumaceans (Crustacea, Diastylidade) from the Brazilian waters. Trav. Mus. Hist. nat. "Grigoire Antipa", 31: 387-395.

Pires, A.M.S. - 1992. Structure and dynamics of benthic megafauna on the continental shelf offshore of Ubatuba, southeastern Brazil. Mar. Ecol. Prog. Ser., 86(1): 63-76.

Pires-Vanin, A.M.S . - 1993. Estrutura e função do ecossistema de plataforma continental do Atlântico Sul brasileiro. Publção esp. Inst. oceanogr.,10:1-245.

Roccatagliata, D. - 1985. Three new species of the genus Cyclaspis (Cumacea) from the south-west Atlantic with a redescription of Cyclaspis platymerus Zimmer, 1844. Crustaceana, 49(2): 177-192.

Roccatagliata, D. - 1986. On some Cyclaspis (Cumacea) from the South American Atlantic coast with the description of two new species. Crustaceana, 50(2): 113-132.

Roccatagliata, D. - 1989. The genus Cyclaspis (Cumacea); a new species and additional records of the distribution. Crustaceana, 56(1): 39-46.

Roccatagliata, D. and P.S. Moreira. - 1987. Four Cyclaspis species (Cumacea) from South American Atlantic coast. Crustaceana, 52(1): 61-77.

Sartor, S. - 1989. Composição e distribuíção dos Brachyura (Crustacea, Decapoda), no litoral norte do Estado de São Paulo. Tese de doutorado, Universidade de São Paulo.

Suguio, K. - 1973. Introdução à Sedimentologia. Blucher / EDUSP.

Valério-Berardo, M.T. - 1992. Composição e distribuição da fauna de Amphipoda de fundos não consolidados da região de Ubatuba (SP, Brasil). Tese de doutorado. Universidade de São Paulo.

Vernberg, F.J. and W.B. Vernberg. - 1983. The biology of Crustacea - Environmental Adaptations. Academic Press.

Weston, D.P. - 1988. Macrobenthos - sediment relationships on the continental shelf off Cape Hatteras North Carolina. Continent. Shelf Res., 8(3): 267-286.

Wieser, W. - 1956. Factors influencing the choice of substratum in Cumella vulgaris Hart (Crustacea, Cumacea). Limnol. Oceanogr.,1(1): 274-285.

Scient. ed.: J.M. Gili 